\title{
A Unique Fifteen Level Inverter Topology for Grid Connected Applications
}

\author{
Kalagotla.Chenchireddy, V. Jegathesan, L. Ashok Kumar
}

\begin{abstract}
This paper proposes a solitary stage fifteen-level inverter utilizing seven switches, with a novel pulse width-balanced control strategy. The Proposed staggered inverter yield voltage level ascending by utilizing less number of switches driven by the multicarrier adjustment systems. The inverter is equipped for creating fifteen level of output voltage from the dc supply voltage. The proposed framework was checked through reproduction and executed in a model.
\end{abstract}

\section{Keywords: Multilevel Inverter, Harmonics, Switching Loss}

\section{INTRODUCTION}

Electrical power generation, transmission and distribution major role in developing country. But conventional energy sources, decreasing fossil fuels, coal and firewood. The importance of renewable energy sources, increasing day to day life. Renewable energy sources like solar, wind, tidal, biomass. All these sources, solar and wind advanced power electronics. We need a suitable converter for converting DC to AC in solar. These papers design fifteen level inverters.

Multilevel inverter designed [1] with minimization of switching frequency. Space vector modulation technique most effective technique for minimization switching frequency and increasing reliability, efficiency, decreasing complexity. Reduced Common mode voltage, switching loss and in harmonic distortion. Multilevel inverter [2] used space vector modulation technique.

Common mode voltage, high switching loss, modulation depth and high harmonic distortion common problems in multilevel inverter. These problems reduced using space vector modulation scheme in cascaded multilevel inverter. Finally improved overall performance in MLI [3]. Reduced zero-order voltage and find out shortest switching path for multilevel inverter. In this paper, a novel multilevel inverter has been proposed using a reduced amount of number of switching for 15 levels. These multilevel inverter only seven switches and three DC sources.

\section{PROPOSED TOPOLOGY}

The main objective of this topology is to improve the quality output voltage of the multilevel inverter. An

\section{Revised Manuscript Received on April 12, 2019.}

Kalagotla.Chenchireddy, Research scholar, Dept of EEE, Karunya Institute of Technology and Sciences., Coimbatore, T.N, India. (Email : Chenchireddy.kalagotla@gmail.com)

Dr V. Jegathesan, Associate Professor Dept of EEE, Karunya Institute of Technology and Sciences, Coimbatore, T.N, India. (Email : jegathesan@karunya.edu)

Dr L. Ashok Kumar, Professor Department of EEE, PSG College of technology, Coimbatore, T.N, India. (Email : askipsg@gmail.Com) important issue MLI designed is that to produce almost sinusoidal output voltage waveform and to eliminate lower order harmonics.

\section{A. Fifteen Level Multilevel Inverter}

A fifteen level proposed inverter uses only seven switches compared to cascaded H-bridge multilevel inverter which uses 16 switches and three separate dc sources. Fifteen levels Cascaded H-bridge [4] voltage source inverter designed and eliminated harmonics in MLI. But cascaded type inverter used 12 switches. The proposed inverter less switches compare to other inverters like diode clamped multilevel inverter, flying capacitor multilevel inverter, cascaded multilevel inverter. Diode clamped MLI used more diodes and more switches single voltage source. Flying capacitor multilevel inverter capacitors balancing difficult.

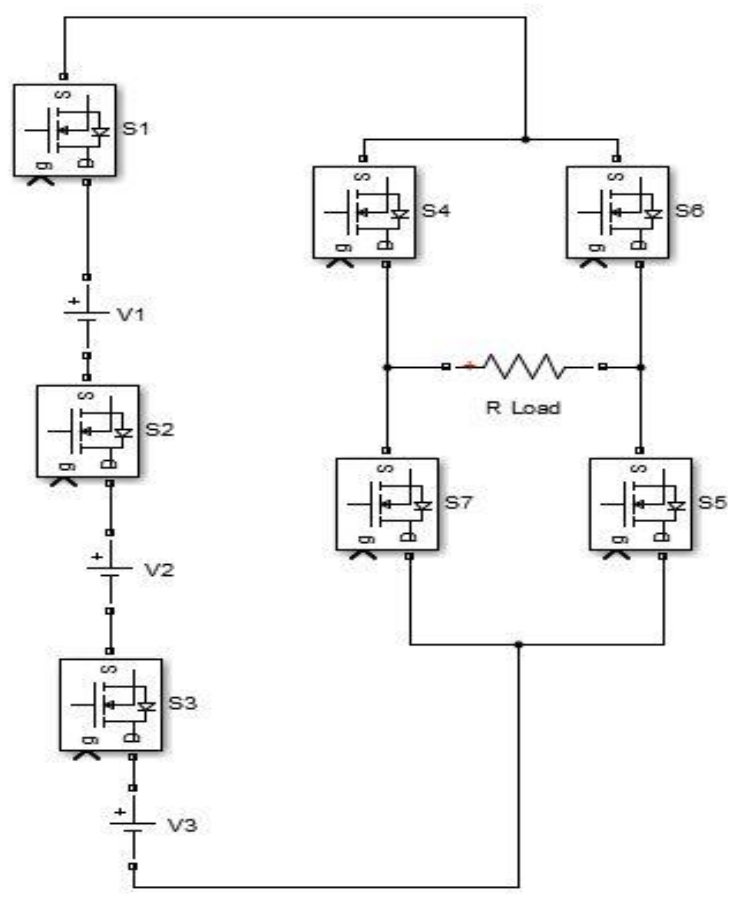

Fig.1 proposed power circuit for 15-level output.

Circuit diagram of proposed fifteen level multilevel inverter is shown in fig. 1 . for generating 15 level, the proposed inverter uses three cells that mean it contains three swatches and three diodes in adding with the one H-bridge. Table I shows the switching sequence used for creating fifteen levels for output voltages. 
Table I: Switching Pattern for Fifteen Level Inverter

\begin{tabular}{|c|c|c|c|c|c|c|c|c|}
\hline Level & SW1 & sW2 & SW3 & SW4 & SW5 & SW6 & SW7 & $\begin{array}{l}\text { Outp } \\
\text { ut } \\
\text { volta } \\
\text { ge }\end{array}$ \\
\hline 1 & 1 & 1 & 1 & 0 & 0 & 1 & 1 & $84 \mathrm{~V}$ \\
\hline 2 & 0 & 1 & 1 & 0 & 0 & 1 & 1 & $72 \mathrm{~V}$ \\
\hline 3 & 1 & 0 & 1 & 0 & 0 & 1 & 1 & $60 \mathrm{~V}$ \\
\hline 4 & 0 & 0 & 1 & 0 & 0 & 1 & 1 & $48 \mathrm{~V}$ \\
\hline 5 & 1 & 1 & 0 & 0 & 0 & 1 & 1 & $36 \mathrm{~V}$ \\
\hline 6 & 0 & 1 & 0 & 0 & 0 & 1 & 1 & $24 \mathrm{~V}$ \\
\hline 7 & 1 & 0 & 0 & 0 & 0 & 1 & 1 & $12 \mathrm{~V}$ \\
\hline 8 & 0 & 0 & 0 & 1 & 0 & 0 & 0 & 0 \\
\hline 9 & 1 & 0 & 0 & 1 & 1 & 0 & 0 & $-12 \mathrm{~V}$ \\
\hline 10 & 0 & 1 & 0 & 1 & 1 & 0 & 0 & $-24 \mathrm{~V}$ \\
\hline 11 & 1 & 1 & 0 & 1 & 1 & 0 & 0 & $-36 \mathrm{~V}$ \\
\hline 12 & 0 & 0 & 1 & 1 & 1 & 0 & 0 & $-48 \mathrm{~V}$ \\
\hline 13 & 1 & 0 & 1 & 1 & 1 & 0 & 0 & $-60 \mathrm{~V}$ \\
\hline 14 & 0 & 1 & 1 & 1 & 1 & 0 & 0 & $-72 \mathrm{~V}$ \\
\hline 15 & 1 & 1 & 1 & 1 & 1 & 0 & 0 & $-84 \mathrm{~V}$ \\
\hline
\end{tabular}

\section{SIMULATION RESULTS}

The proposed fifteen level inverter is recreated utilizing Matla/Simulink. The recreation is made in open circle. Here the information voltage can be chosen as $12 \mathrm{~V}, 24 \mathrm{VBand} 48 \mathrm{~V}$ to get a yield voltage as $84 \mathrm{~V}$. The Matlab/Simulink model is as indicated fig. 2 the three dissimilar to include voltages as given $12 \mathrm{~V}, 24 \mathrm{~V}$ and $48 \mathrm{~V}$. These voltages are given to 7 unique switches which are related proposed 15 levels MLI.

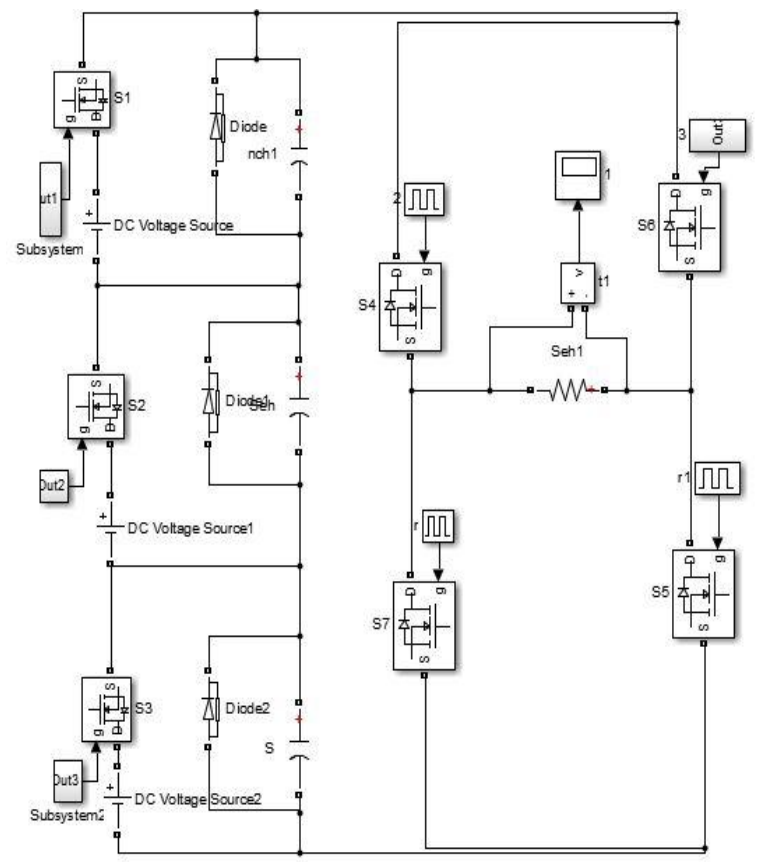

Fig. 2 Fifteen level inverter topology

TABLE 2: Simulation parameters of fifteen level inverter system

\begin{tabular}{|l|l|}
\hline parameter & value \\
\hline DC voltage source(V) & $\begin{array}{l}\mathrm{V}=12, \mathrm{~V}_{1}=24, \mathrm{~V}_{2}=4 \\
8\end{array}$ \\
\hline Capacitor's (nF) & 100 \\
\hline R-load (ohm's) & 100 \\
\hline Output voltage (peak to paek) & $74 \mathrm{~V}$ \\
\hline Utility frequency (HZ) & 50 \\
\hline Inductance H & 100 \\
\hline
\end{tabular}

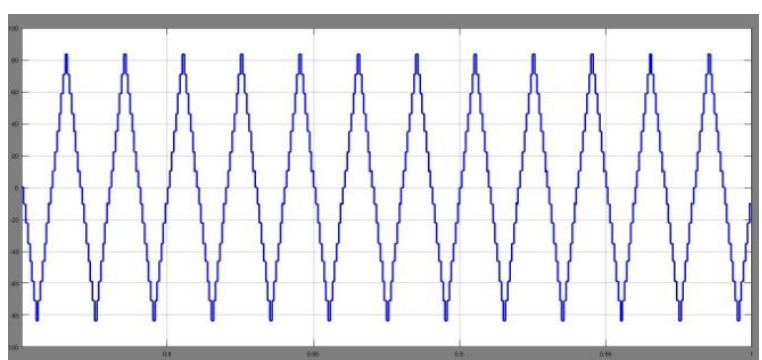

Fig.3 Simulation result for fifteen level multilevel inverter with R-Load

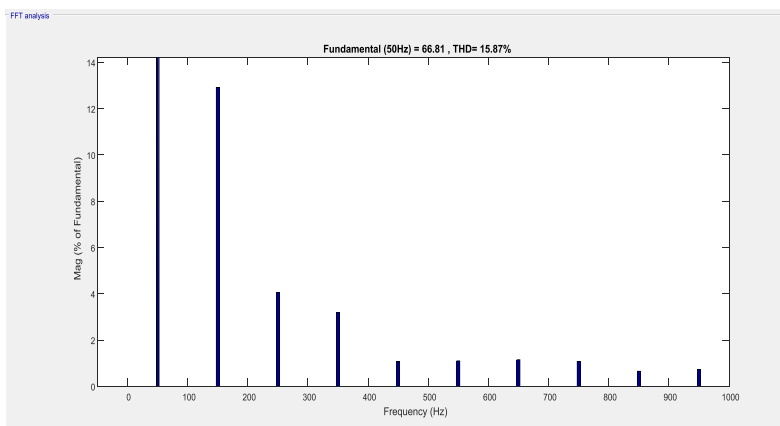

Fig.4 harmonic spectrum for fifteen level R-load output voltage 


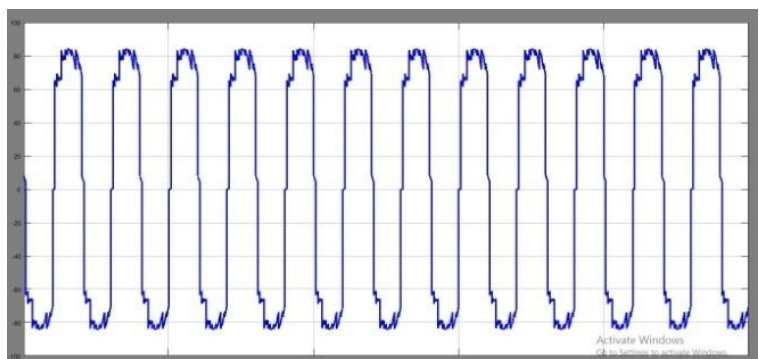

Fig.5 Simulation result for fifteen level multilevel inverter with L-Load

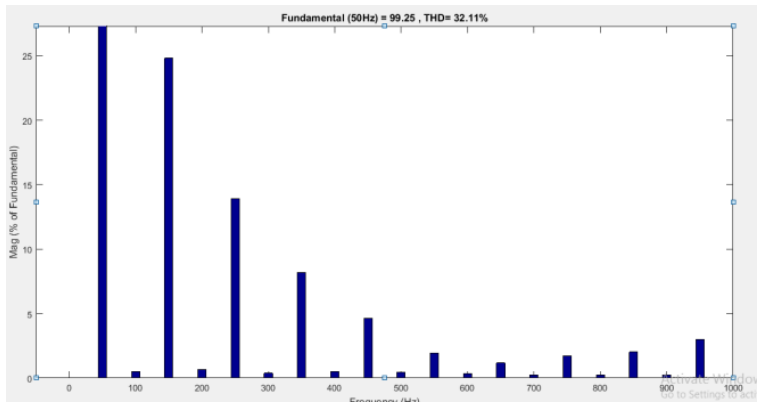

Fig.6 harmonic spectrum for fifteen levels L-load output voltage

\section{THE EXPERIMENTAL RESULTS}

The proposed 15 level inverter hardware components. Three DC sources with reduce number of switches. Three input sources given from solar panel. Boost converter used for increasing voltage. Multilevel inverter circuit reduced seven switches. PIC-microcontroller used for generating pulses for multilevel inverter.

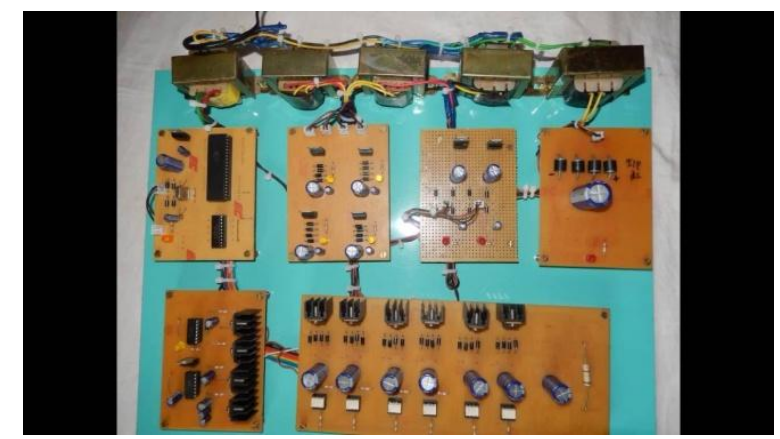

Fig 7. Experimental Setup Of 15- Level Inverter

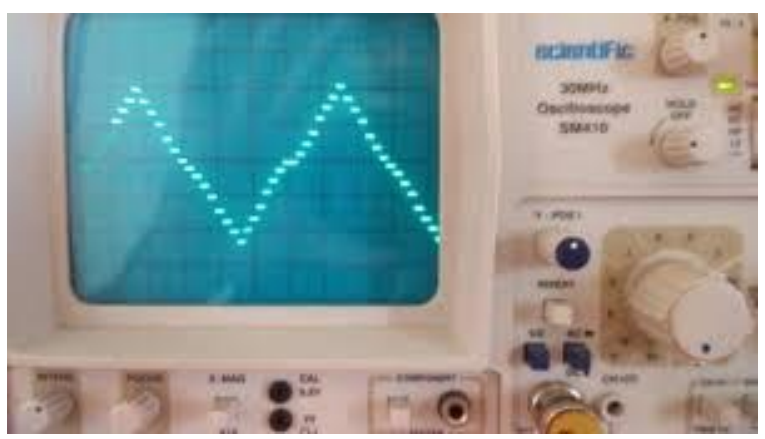

Fig 8. Output Voltage Waveform

\section{CONCLUSION}

Multilevel Inverter is the most generally utilized. It acting increasingly huger job in numerous mechanical applications.
In this paper a Novel Fifteen Level Inverter is presented. An extremely enormous yield voltage is acquired with the proposed converter and the voltage weight on the power gadgets is decreased. In addition it requires 7 MOSFETs. 15 levels acquire with less consonant twisting.

\section{REFERENCES}

1. Yong -Chao Liu, Xinglai Ge, Qidi Tang and Bin Gou "two modified SVPWM algorithms for common-mode voltage reduction in eight-switch three-phase inviters" electronics letter 11th may 2017 Vol.53 N0.10 pp.676-678.

2. Ifran Ahmed, Vijay B.Borghate, Amarendra Matsa, M. Meshram, H.M.Suryawanshi " simplified space vector modulation techniques for multilevel inverters" IEEE 2015.

3. Amit Kumar Gupta, Ashwin M.Khambadkone "a space vector modulation scheme to reduce common mode voltage for cascaded multilevel inverters" IEEE 2017.

4. Zainal Salam, Ahmed Majed, Abdul Moeed Amjad "Design and implementation of 15-level cascaded multi-level voltage source inverter with harmonics elimination pulse-width modulation using differential evolution method" IET Power electronics 18th june 2015. 